\title{
Comparative Physicochemical Evaluation of Biofield Treated Phosphate Buffer Saline and Hanks Balanced Salt Medium
}

\author{
Mahendra Kumar Trivedi ${ }^{1}$, Alice Branton ${ }^{1}$, Dahryn Trivedi ${ }^{1}$, Gopal Nayak ${ }^{1}$, \\ Rakesh Kumar Mishra ${ }^{2}$, Snehasis Jana, ${ }^{2, *}$ \\ ${ }^{1}$ Trivedi Global Inc., Henderson, USA \\ ${ }^{2}$ Trivedi Science Research Laboratory Pvt. Ltd., Bhopal, Madhya Pradesh, India
}

Email address:

publication@trivedisrl.com (S. Jana)

\section{To cite this article:}

Mahendra Kumar Trivedi, Alice Branton, Dahryn Trivedi, Gopal Nayak, Rakesh Kumar Mishra, Snehasis Jana. Comparative Physicochemical Evaluation of Biofield Treated Phosphate Buffer Saline and Hanks Balanced Salt Medium. American Journal of BioScience. Vol. 3, No. 6, 2015, pp. 267-277. doi: 10.11648/j.ajbio.20150306.20

\begin{abstract}
Phosphate buffer saline (PBS) has numerous biological and pharmaceutical applications. Hank buffer salt (HBS) has been used as a medium for tissue culture applications. This research study was aimed to investigate the influence of Mr. Trivedi's biofield energy treatment on physicochemical properties of the PBS and HBS. The study was executed in two group's i.e. control and treated. The control group was kept aside as control and treated group had received the biofield energy treatment. The control and treated samples were further characterized by X-ray diffraction (XRD), differential scanning calorimetry (DSC), thermogravimetric analysis (TGA), and Fourier transform infrared (FT-IR) spectroscopy. The XRD analysis indicated the increase in crystallite size by $5.20 \%$ in treated PBS as compared to the control. Similarly, the treated HBS also showed increase in

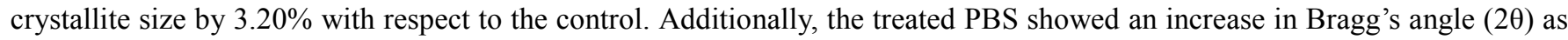
compared to the control sample. However, a decrease in Bragg's angle of XRD peaks of the treated sample was noticed in the treated HBS. The DSC analysis of the control PBS showed melting temperature at $224.84^{\circ} \mathrm{C}$; however melting temperature was not observed in the treated sample. However, DSC analysis of the treated HBS showed an increase in melting temperature $\left(152.83^{\circ} \mathrm{C}\right)$ in comparison with the control $\left(150.60^{\circ} \mathrm{C}\right)$. Additionally, the latent heat of fusion of the treated HBS was increased substantially by $108.83 \%$ as compared to the control. The TGA thermogram of the treated PBS showed an increase in onset of thermal degradation $\left(212^{\circ} \mathrm{C}\right)$ as compared to the control $\left(199^{\circ} \mathrm{C}\right)$. Whereas, the treated HBS showed less weight loss comparing with the control sample. This indicated the increase in thermal stability of the both the treated PBS and HBS samples. The FT-IR spectroscopic analysis of treated PBS showed alterations in the frequency of the functional groups such as $\mathrm{O}-\mathrm{H}, \mathrm{C}-\mathrm{H}, \mathrm{P}=\mathrm{O}$, $\mathrm{O}=\mathrm{P}-\mathrm{OH}$, and $\mathrm{P}-\mathrm{OH}$ as compared to the control. Additionally, the FT-IR spectrum of the treated HBS showed increase in frequency of calcium chloride phase $\left(1444 \rightarrow 1448 \mathrm{~cm}^{-1}\right)$ as compared to the control sample. Altogether, it was observed that biofield energy treatment had caused physical, thermal and spectral changes in the treated samples as compared to the control. It is assumed that biofield energy treated PBS and HBS could be a good prospect for biological and tissue culture applications.
\end{abstract}

Keywords: Phosphate Buffer Saline, Hank Buffer Salt, Biofield Energy Treatment, X-ray Diffraction, Thermal Analysis

\section{Introduction}

Phosphate buffer saline (PBS) is a buffer solution commonly used in biological research. It is mainly a water-based salt solution containing sodium phosphate and sodium chloride. PBS is known to be isotonic to the biological cells, hence it has many applications. It has been used in laboratory protocols for dilutions, washing cell suspensions, rinsing culture flaks and plates as well as additives to cell culture media [1-6]. PBS is commercially available in different formulation with calcium and magnesium (+/+ PBS) or without (-/- PBS) [7]. Lichtenauer et al. reported that PBS might have an influence on the human peripheral mononuclear cells under different culture conditions. They elaborated that these alterations of extracellular conditions might influence several functions such as secretion of cytokines, proliferative responses and cell death [8]. Moreover, PBS-based buffers 
have been used in pharmaceutical industries for assessing the drug release, drug stability as well as buffer for high-performance liquid chromatography (HPLC) [9]. Additionally, PBS has also been used as a buffer in the microbial fuel cells to maintain the $\mathrm{pH}$ conditions and solution conductivity [10]. The salt solution has been used to maintain the medium within the physiological $\mathrm{pH}$ range. This is also used to maintain the intracellular and extracellular osmotic balance. Hank's balanced salt (HBS) solution is used in cell culture applications. It is designed for use in cells maintained with less $\mathrm{CO}_{2}$ environment or $\mathrm{CO}_{2}$ free environment [11].

Stability of buffer solution is an important requirement for its intended uses in pharmaceutical and biological applications It was reported that stability of buffer solution can be affected by temperature, chemical, light, etc. [12]. Thus, it is envisaged that stability of buffer solutions such as PBS and HBS could be improved using some alternative methods. Recently, biofield energy treatment was used as a lucrative method for physicochemical modifications of various materials.

Biofield energy therapies are considered under complementary and alternative medicine (CAM). These kind of therapies contains practices based on subtle energy fields, and it is envisaged that human beings are permeated with a subtle form of energy [13]. It is believed that biofield therapies are effective in reducing stress such as daily life stress and stress of patients receiving terminal care [14]. It was reported that healing practitioners can channel the energy to the patients and confer positive results. Therefore, it is suggested that human beings have the ability to harness the energy from the environment/Universe and can transmit into any object (living or non-living) around the Globe. The object(s) will always receive the energy and responding in a useful manner that is called biofield energy. Moreover, biofield energy treatment that comes under the category of CAM therapies have been approved by the prestigious National Institute of Health (NIH)/The National Centre for Complementary and Alternative Medicine (NCCAM), as an alternative treatment in the healthcare sector [15]. Mr. Mahendra Kumar Trivedi is a well-known healer of biofield energy who can alter the physicochemical properties of materials such as metals [16], organic compound [17], drugs [18], and polymers [19]. Additionally, the biofield energy treatment is also known as The Trivedi effect ${ }^{\circledR}$ has improved the production in the field of agriculture [20] and altered the phenotypic characteristics of pathogenic microbes [21]. Therefore, after conceiving the above-mentioned outcomes of biofield energy treatment, and properties of PBS and HBS, authors, have planned to investigate the impact of biofield energy on physicochemical properties of these buffers.

\section{Materials and Methods}

Phosphate buffer saline (PBS) and Hank's balanced salt (HBS) solution were procured from Himedia Laboratories, India, and the samples were divided into two parts. The one part was kept aside as a control sample, while the other part was subjected to Mr. Trivedi's unique biofield energy treatment and labelled as treated sample. The treated group was in sealed pack and handed over to Mr. Trivedi for biofield energy treatment under standard laboratory conditions. Mr. Trivedi gave the energy treatment through his energy transmission process to the treated sample without touching the sample. The control and treated samples were characterized by different analytical techniques such as X-ray diffraction, differential scanning calorimetry, thermogravimetric analysis, and Fourier transform infrared spectroscopy.

\subsection{X-ray Diffraction (XRD)}

XRD analysis of control and treated samples (PBS and HBS) were evaluated using X-ray diffractometer system, Phillips, Holland PW 1710 which consist of a copper anode with nickel filter. XRD system had a radiation of wavelength $1.54056 \AA$. The average crystallite size $(G)$ was computed using formula:

$$
\mathrm{G}=\mathrm{k} \lambda /(\mathrm{b} \operatorname{Cos} \theta)
$$

Here, $\lambda$ is the wavelength of radiation used, $b$ is full-width half-maximum (FWHM) of peaks and $\mathrm{k}$ is the equipment constant $(=0.94)$. Percentage change in average crystallite size was calculated using following formula:

Percentage change in crystallite size $=\left[\left(\mathrm{G}_{\mathrm{t}}-\mathrm{G}_{\mathrm{c}}\right) / \mathrm{G}_{\mathrm{c}}\right] \times 100(2)$

Where, $\mathrm{G}_{\mathrm{c}}$ and $\mathrm{G}_{\mathrm{t}}$ are denoted as crystallite size of control and treated powder samples, respectively.

\subsection{Differential Scanning Calorimetry (DSC)}

The control and treated samples (PBS and HBS) were analyzed using Pyris-6 Perkin Elmer DSC at a heating rate of $10^{\circ} \mathrm{C} / \mathrm{min}$ and the air was purged at a flow rate of $5 \mathrm{~mL} / \mathrm{min}$. The predetermined amount of sample was kept in an aluminum pan and closed with a lid. A reference sample was prepared using a blank aluminum pan. The percentage change in latent heat of fusion was calculated using following equations:

$$
\begin{aligned}
& \% \text { Change in latent heat of fusion } \\
& =\left[\Delta \mathrm{H}_{\text {Treated }}-\Delta \mathrm{H}_{\text {Control }}\right] / \Delta \mathrm{H}_{\text {Control }} \times 100
\end{aligned}
$$

Where, $\Delta \mathrm{H}_{\text {Control }}$ and $\Delta \mathrm{H}_{\text {Treated }}$ are the latent heat of fusion of control and treated samples, respectively.

\subsection{Thermogravimetric Analysis-Differential Thermal Analysis (TGA-DTA)}

A Mettler Toledo simultaneous TGA and differential thermal analyzer (DTA) was used to investigate the thermal stability of control and treated samples (PBS and HBS). The rate of heating was $5^{\circ} \mathrm{C} / \mathrm{min}$ and samples were heated in the range of room temperature to $400^{\circ} \mathrm{C}$ under air atmosphere.

\subsection{FT-IR Spectroscopy}

The FT-IR spectra were recorded on Shimadzu's Fourier transform infrared spectrometer (Japan) with the frequency range of $4000-500 \mathrm{~cm}^{-1}$. 


\section{Results and Discussion}

\subsection{X-ray Diffraction}

X-ray diffraction studies were conducted to investigate the crystalline nature of the control and treated samples. XRD diffractogram of control and treated PBS are presented in Fig. 1. The XRD diffractogram of the control PBS showed intense crystalline peaks at Bragg's angle $27.31^{\circ}, 31.62^{\circ}, 45.36^{\circ}$, $45.50^{\circ}, 56.39^{\circ}, 66.16^{\circ}$, and $75.23^{\circ}$. However, the treated PBS showed the occurrence of intense peaks at Bragg's angle $27.30^{\circ}, 31.65^{\circ}, 45.40^{\circ}, 45.54^{\circ}, 56.43^{\circ}, 66.19^{\circ}$ and $75.26^{\circ}$. The result indicated an increase in Bragg's angle at $31.62 \rightarrow 31.65$, $45.36^{\circ} \rightarrow 45.40^{\circ}$, $45.50^{\circ} \rightarrow 45.54^{\circ}$, $56.39^{\circ} \rightarrow 56.43^{\circ}$ $66.16^{\circ} \rightarrow 66.19^{\circ}$, and $75.23^{\circ} \rightarrow 75.26^{\circ}$ in the treated sample as compared to the control. It was reported that presence of tensile stress in molecules might cause an increase in Bragg's angle of the samples. Thus, it is assumed that biofield energy treatment might cause the emergence of tensile stress in treated PBS molecules that led to increase in Bragg's angle of the sample as compared to the control. The crystallite size was computed from XRD data of control and treated PBS and results are presented in Fig. 2. The crystallite size of the control PBS was $107.95 \mathrm{~nm}$, and it was increased to 113.56 $\mathrm{nm}$ in the treated sample. The result demonstrated $5.20 \%$ increase in crystallite size of the treated sample as compared to the control.
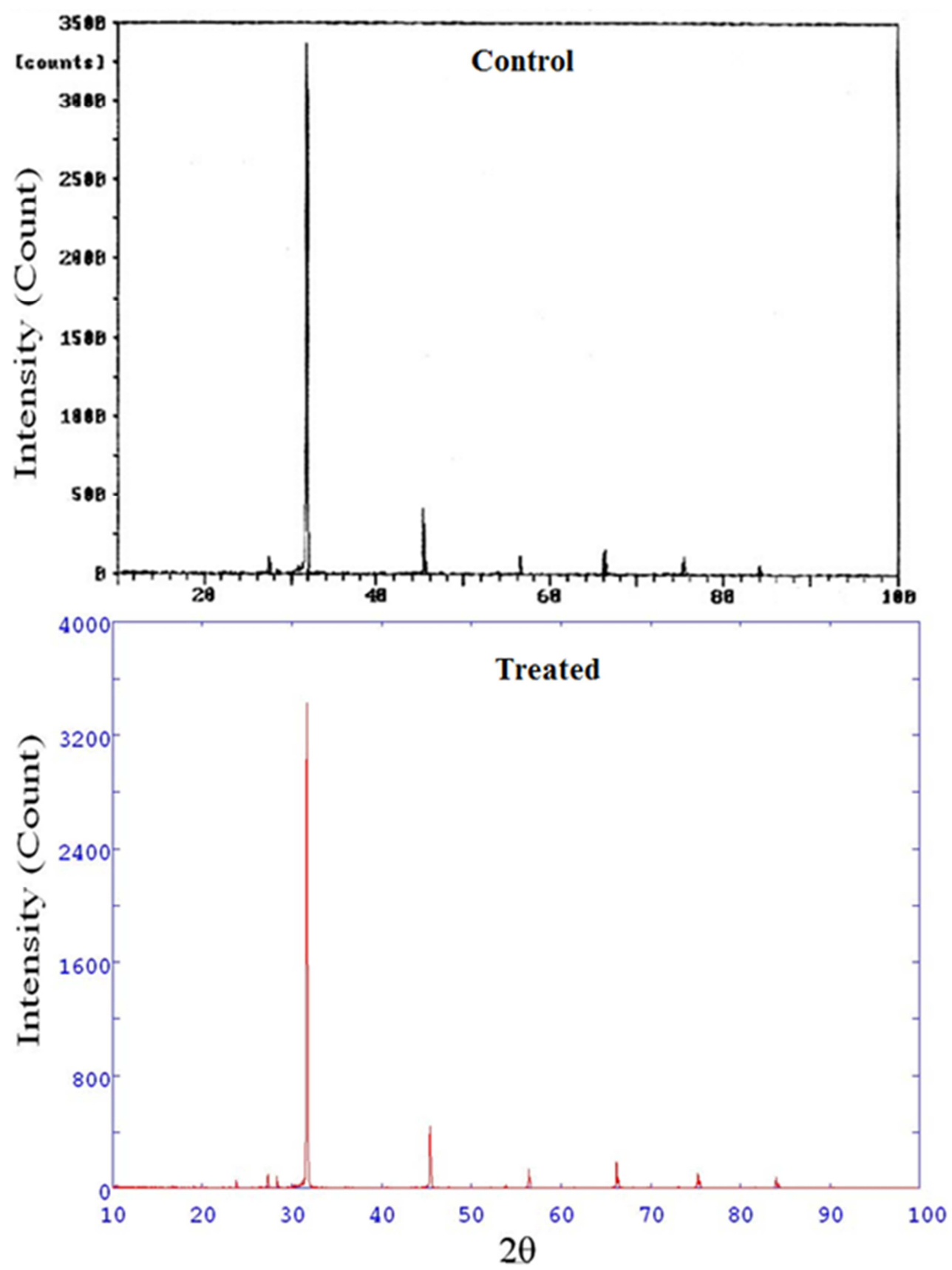

Figure 1. XRD diffractograms of the control and treated phosphate buffer saline. 


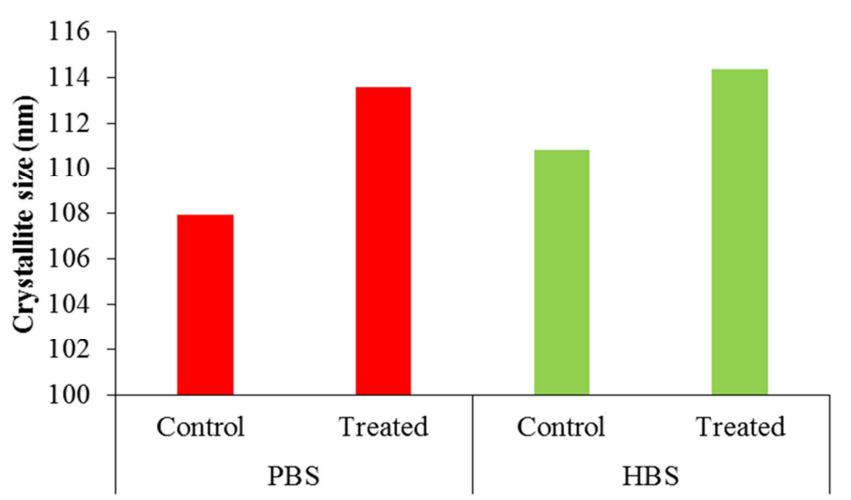

Figure 2. Crystallite size of the control and treated phosphate buffer saline and hanks balanced salt.

XRD diffractogram of the control and treated HBS are depicted in Fig. 3. The XRD diffractogram of the control sample showed intense crystalline peaks at Bragg's angle at $27.35^{\circ}, 28.33^{\circ}, 31.69^{\circ}, 31.78^{\circ}, 45.43^{\circ}, 56.46^{\circ}, 66.22^{\circ}$, and $75.26^{\circ}$. However, the treated sample showed XRD peaks at Bragg's angle $27.31^{\circ}, 28.31^{\circ}, 31.65^{\circ}, 31.75^{\circ}, 45.41^{\circ}, 56.43^{\circ}$, $66.20^{\circ}$ and $75.27^{\circ}$. The result showed a decrease in Bragg's angle of the treated sample $27.35^{\circ} \rightarrow 27.31^{\circ}, 28.33^{\circ} \rightarrow 28.31^{\circ}$, $31.69^{\circ} \rightarrow 31.65^{\circ}, \quad 31.78^{\circ} \rightarrow 31.75^{\circ}, \quad 45.43^{\circ} \rightarrow 45.41^{\circ}$, $56.46^{\circ} \rightarrow 56.43^{\circ}$, and $66.22^{\circ} \rightarrow 66.20^{\circ}$ as compared to the control. Additionally, a significant decrease in XRD peak intensity was also observed with respect to the control sample. Inoue and Hirasawa demonstrated an interesting relationship between crystal morphology and XRD peak intensity of gypsum $\left(\mathrm{CaSO}_{4} \cdot 2 \mathrm{H}_{2} \mathrm{O}\right)$. They elaborated that decrease in intensity of XRD peaks might change the crystal morphology of the gypsum samples [22]. Therefore, it is assumed that biofield treatment may led to change in crystal morphology of the treated HBS that might led to depression in the intensity of the XRD peak as compared to the control.
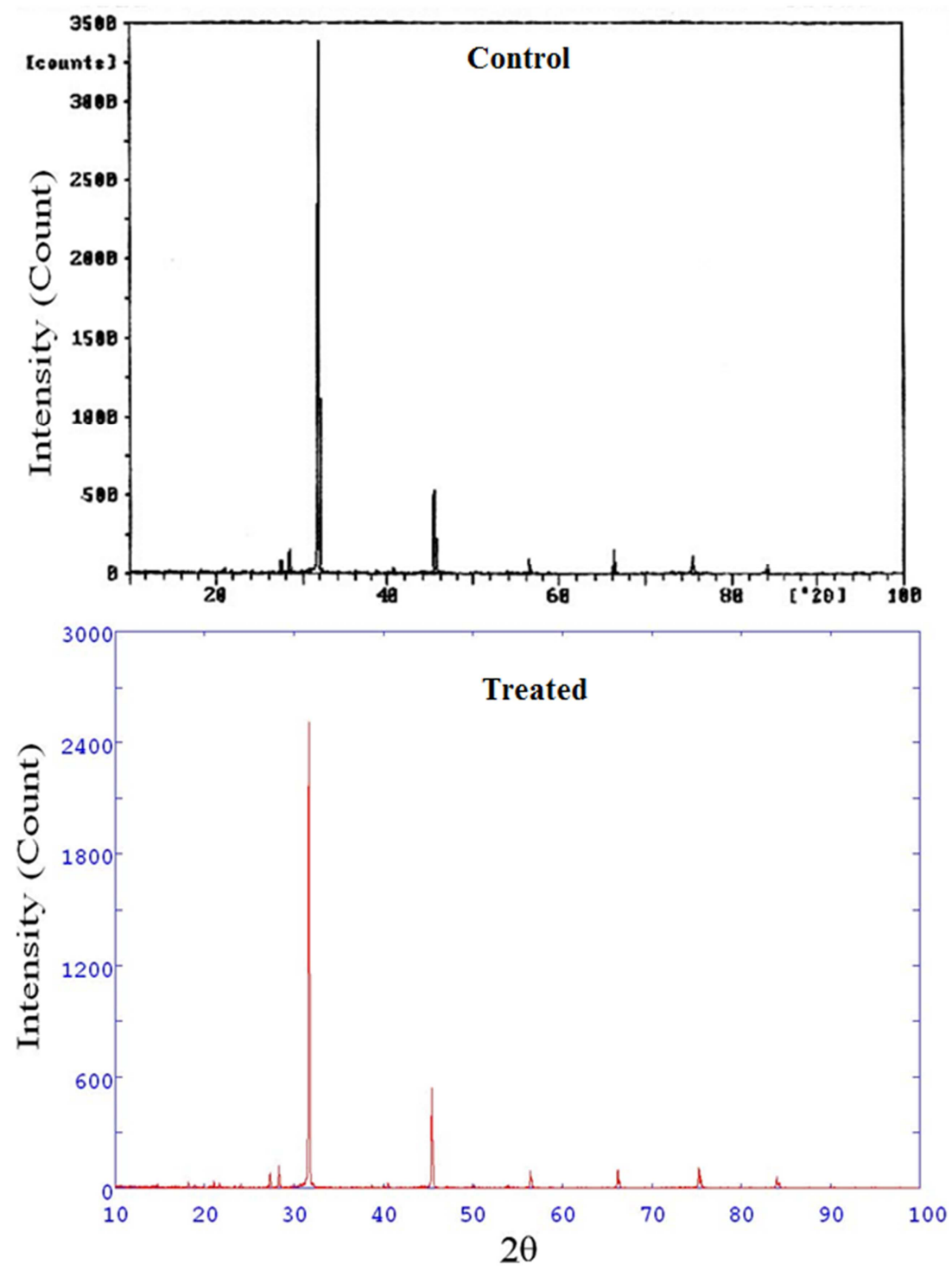

Figure 3. XRD diffractograms of the control and treated hank balanced salt. 
The crystallite size of the control HBS was $110.81 \mathrm{~nm}$, and it was increased to $114.36 \mathrm{~nm}$ in the treated sample. The result suggested the increase in crystallite size by $3.20 \%$ in the treated HBS with respect to the control. The crystallite size is known as a group of molecules having orientation in the same plane. Researchers have shown that modulation in crystallite size directly governs the material properties. Grzmil et al. showed that calcination along with an increase in temperature causes a considerable increase in crystallite size of the materials [23]. Additionally, Jacob et al. during their studies on nano ceramic materials demonstrated that different treating temperature causes an increase in crystallite size [24, 25]. Thus, it is hypothesized that biofield treatment might provide thermal energy that led to the expansion of the crystallite size of the treated PBS and HBS salt as compared to the control.

\subsection{DSC Characterization}

DSC is a thermal analysis technique that is used to investigate the melting temperature, glass transition and latent heat of fusion of the materials. The DSC thermograms of control and treated PBS samples are presented in Fig. 4. The DSC thermogram of control PBS showed two endothermic peaks i.e. at 67.95 and $224.84^{\circ} \mathrm{C}$. The first endothermic peak was due to some bound water in the sample and the second peak may be attributed to the melting of the disodium hydrogen phosphate in the sample. Whereas, the treated PBS showed endothermic peak at $63.39^{\circ} \mathrm{C}$ that was due to bound water in the sample. However, the second endothermic peak was disappeared in the treated sample that might be due to robust crystalline nature of the treated sample as compared to the control.

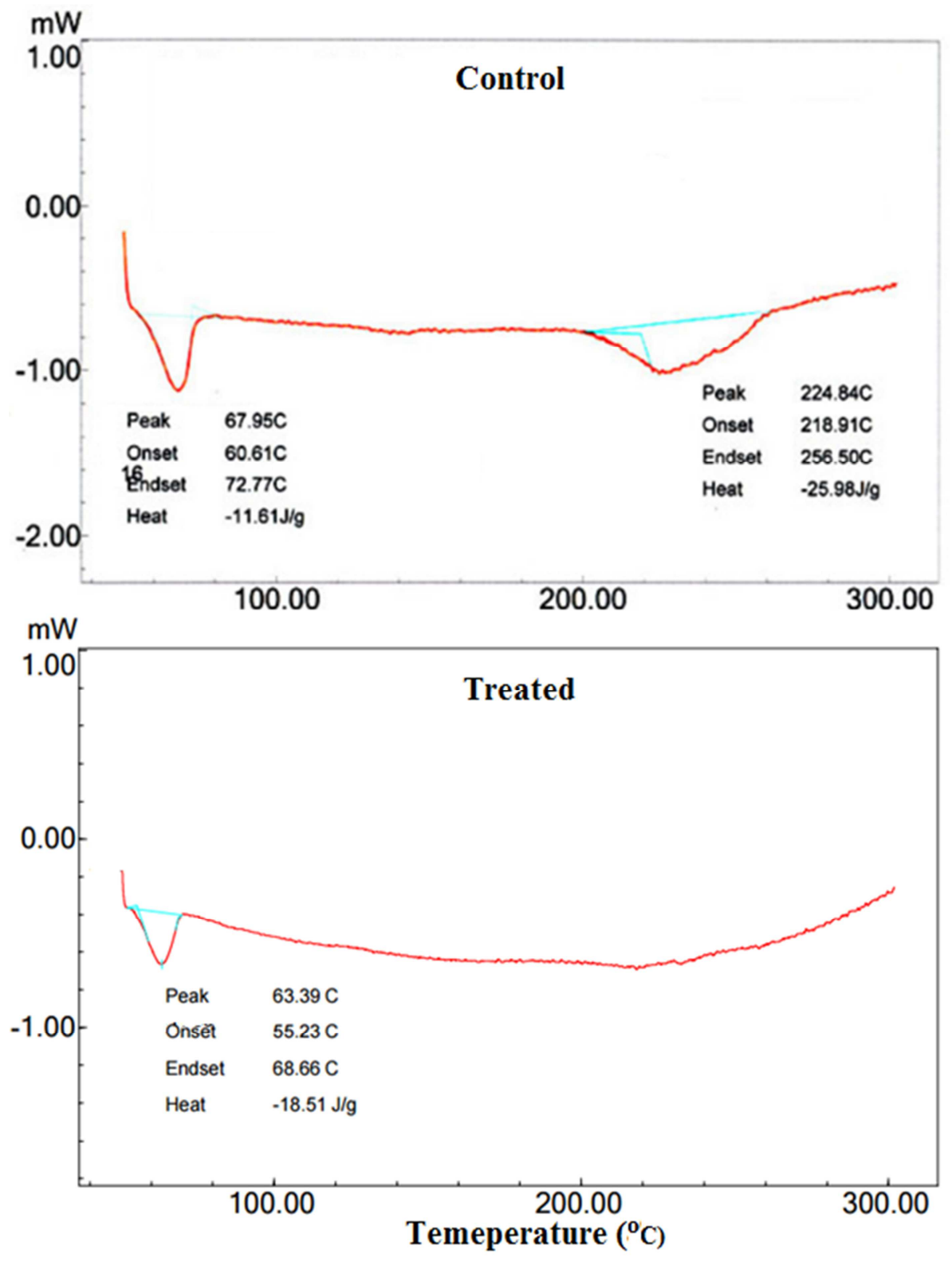

Figure 4. DSC thermograms of control and treated phosphate buffer saline. 

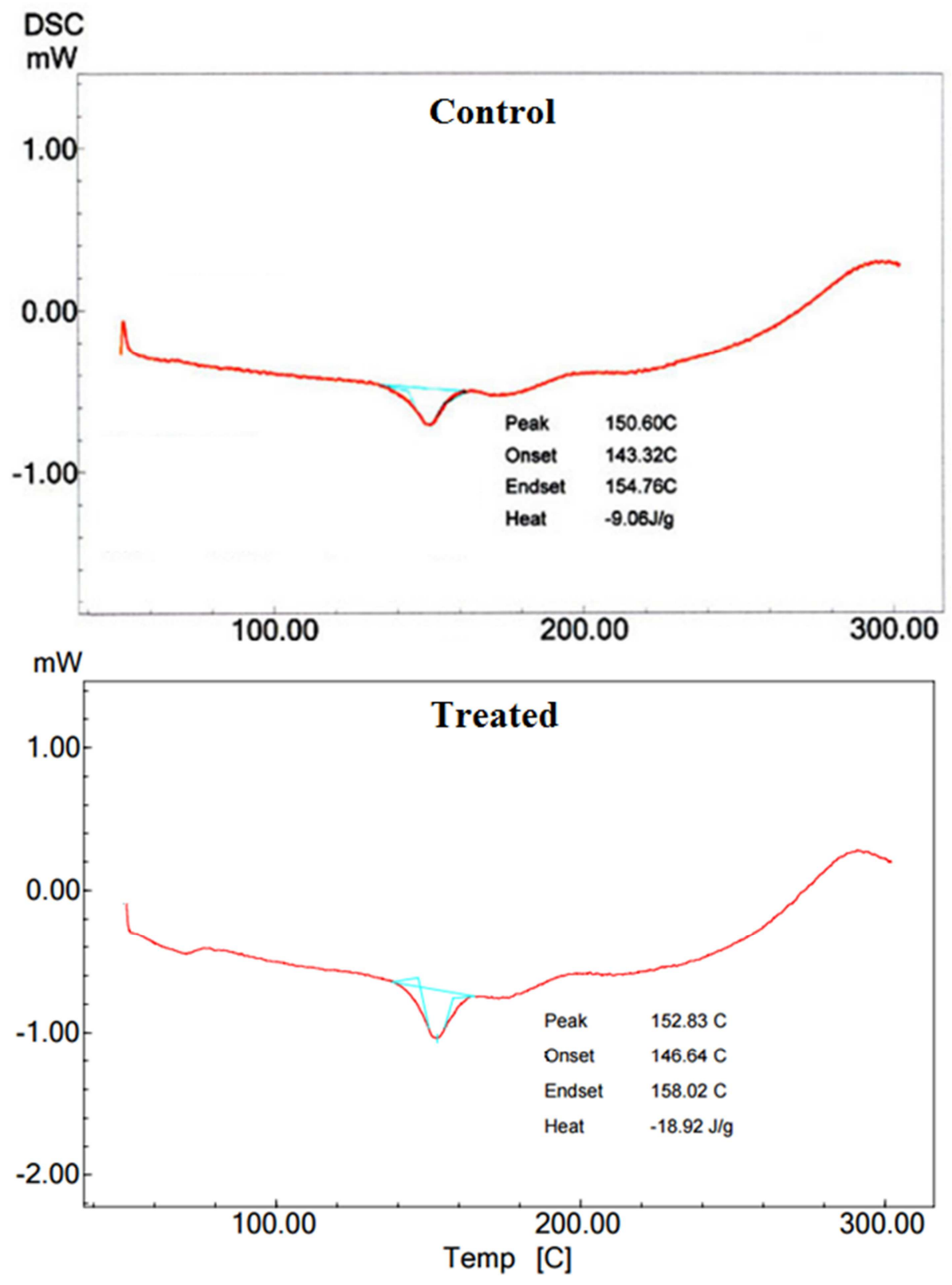

Figure 5. DSC thermograms of control and treated hank buffer salt.

DSC thermogram of the control and treated HBS are presented in Fig. 5. DSC thermogram of control HBS showed an endothermic transition at $150.60^{\circ} \mathrm{C}$ that may be due to melting temperature of the sample. However, the treated HBS showed an endothermic peak at $152.83^{\circ} \mathrm{C}$, attributed to melting temperature of the sample. The increase in endothermic peak might be associated with an increase in thermal stability of the treated HBS. It was previously reported that increase in melting temperature could be correlated to increase in thermal stability [26]. The latent heat of fusion results were recorded from the DSC thermograms. The latent heat of fusion is regarded as heat absorbed during phase transition i.e. solid to the liquid phase of a material. The latent heat of fusion of the control sample was $9.06 \mathrm{~J} / \mathrm{g}$, and it was substantially increased to $18.92 \mathrm{~J} / \mathrm{g}$ in the treated HBS. The result indicated $108.83 \%$ increase in the latent heat of fusion of the treated HBS sample with respect to the control. Recently, biofield energy treatment had altered the latent heat of fusion of indole compound [16].

\subsection{TGA Analysis}

TGA analysis is a thermal technique that is used to measure the thermal decomposition, weight loss, volatilization, and oxidation in the samples. The TGA thermograms of the control and treated PBS are presented in Fig. 6. The TGA thermogram of the control PBS showed three-steps thermal degradation pattern. The first step thermal degradation commenced at around $199^{\circ} \mathrm{C}$ and terminated at around $220^{\circ} \mathrm{C}$. The second step thermal decomposition began at around $221^{\circ} \mathrm{C}$ and terminated at around $246^{\circ} \mathrm{C}$. Further, the third decomposition started at around $336^{\circ} \mathrm{C}$ and terminated at around $361^{\circ} \mathrm{C}$. Contrarily, the TGA thermogram of the treated 
PBS showed one-step thermal degradation pattern. The thermal degradation began at around $212^{\circ} \mathrm{C}$ and terminated at around $270^{\circ} \mathrm{C}$. The result showed that onset of thermal degradation of the treated PBS $\left(212{ }^{\circ} \mathrm{C}\right)$ was higher as compared to the control $\left(199^{\circ} \mathrm{C}\right)$. This may be attributed to increased thermal stability of the biofield energy treated PBS as compared to the control.

TGA thermogram of the control and treated HBS are presented in Fig. 7. The TGA thermogram of the control sample showed commencement of thermal degradation at around $180^{\circ} \mathrm{C}$ and it stopped at around $260^{\circ} \mathrm{C}$. However, the treated sample showed thermal degradation at around $130^{\circ} \mathrm{C}$ and it terminated at around $237^{\circ} \mathrm{C}$. The results indicated that the control and treated sample had lost 10.78 and 5.35\%, respectively from its initial weight during the thermal degradation process. DTG thermogram of the control and treated HBS are shown in Fig. 7. DTG thermogram of the control HBS showed maximum thermal decomposition temperature $\left(\mathrm{T}_{\max }\right)$ at 207.88. However, the treated HBS showed $\mathrm{T}_{\max }$ at $186.31^{\circ} \mathrm{C}$. The result suggested that thermal weight loss in the treated sample was less as compared to the control. This may be regarded as the high thermal stability of the treated sample with respect to the control.

It was reported that crosslinking and conformational changes might induce thermal stability to gamma radiation treated polymer [27]. Therefore, it is assumed that biofield energy treatment might cause the crosslinking and conformational changes in the treated PBS and HBS molecules that leads to increase in thermal stability of the treated samples.

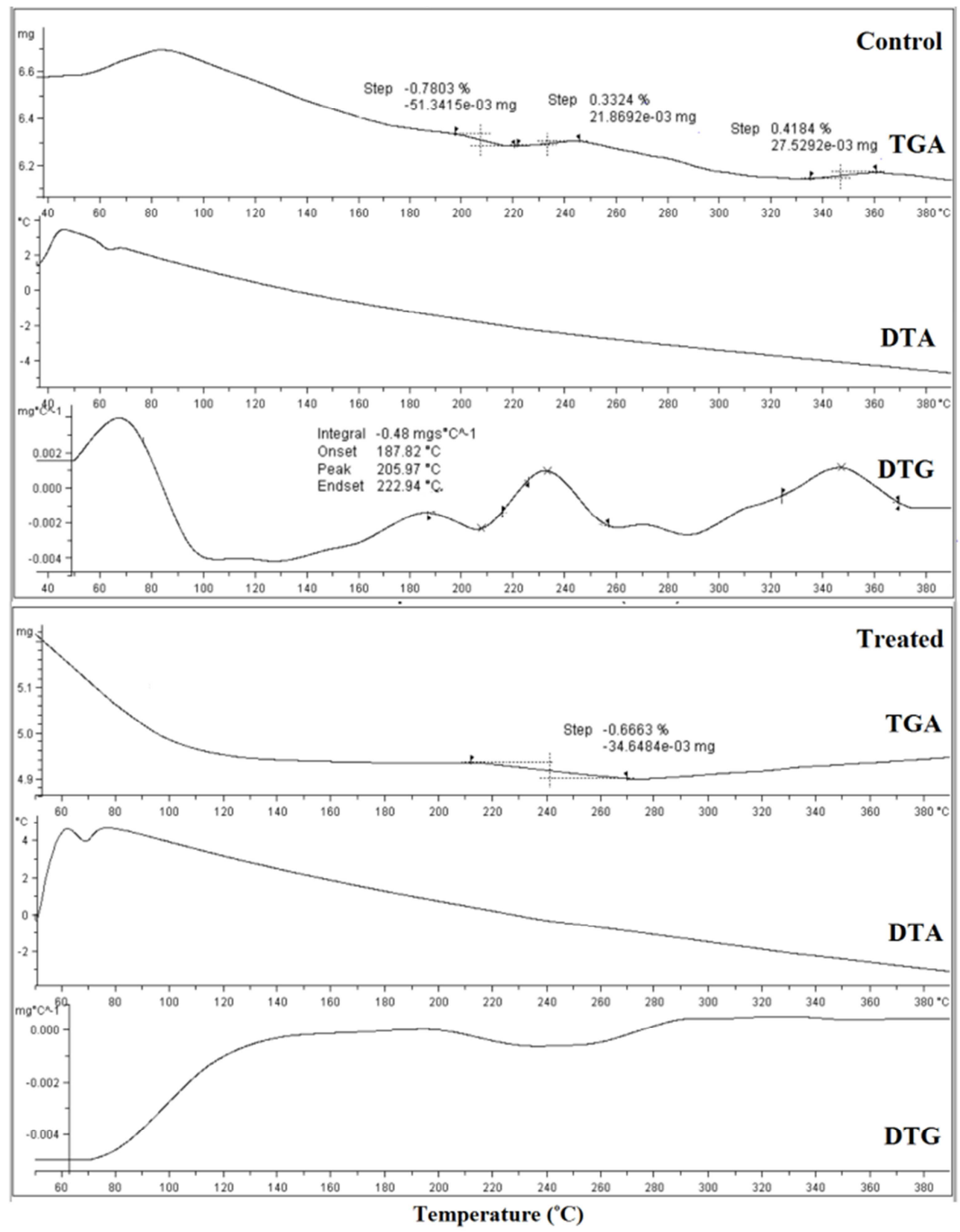

Figure 6. TGA thermograms of control and treated phosphate buffer saline. 


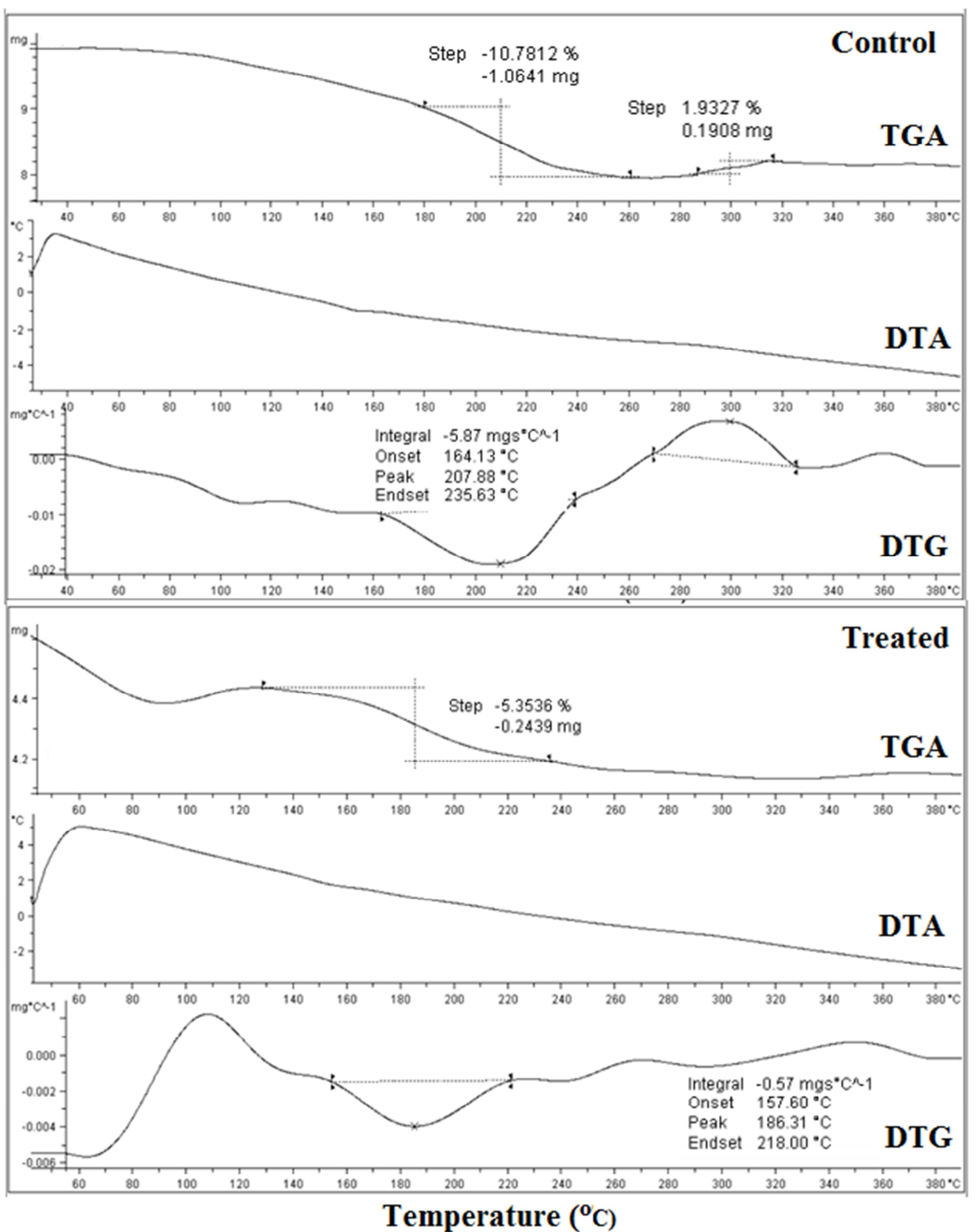

Figure 7. TGA thermograms of control and treated hanks balanced salt.

\subsection{FT-IR Spectroscopy}

FT-IR spectroscopy was used to evaluate the vibrational frequencies of different functional groups present in the samples. FT-IR spectra of the control and treated PBS are depicted in Fig. 8. The characteristic peaks observed in the region of $3373-3440 \mathrm{~cm}^{-1}$ were due to stretching vibration of hydrogen bonded $\mathrm{O}-\mathrm{H}$ group in disodium hydrogen phosphate in the control sample. However, the treated PBS showed these peaks in the region $3369-3440 \mathrm{~cm}^{-1}$. The $\mathrm{P}-\mathrm{OH}$ symmetrical stretching vibration appeared in the region of $2813-2893 \mathrm{~cm}^{-1}$ in the control sample. While, in the treated PBS these peaks appeared at $2827-2879 \mathrm{~cm}^{-1}$. The PO-H symmetrical stretch was observed at $2327 \mathrm{~cm}^{-1}$ and it was shifted to $2337 \mathrm{~cm}^{-1}$ in 
the treated sample. Further, the PO-H bending peak was assigned at $954 \mathrm{~cm}^{-1}$ in the control PBS and in the treated sample it was appeared at $952 \mathrm{~cm}^{-1}$. It was reported that when a $\mathrm{P}-\mathrm{OH}$ group exists with one $\mathrm{P}=\mathrm{O}$ group, an additional broad peak appears in the region of $1750-1630 \mathrm{~cm}^{-1}$ [28]. Similarly, disodium hydrogen phosphate molecules present in control PBS exhibited stretching vibration peaks in the region of $1633-1716 \mathrm{~cm}^{-1}$. However, the treated sample showed these peaks at $1660-1745 \mathrm{~cm}^{-1}$. These peaks were attributed to $\mathrm{O}=\mathrm{P}-\mathrm{OH}$ deformation vibrations in the control and treated sample. The peaks at $1134-1344 \mathrm{~cm}^{-1}$ were might be due to $\mathrm{P}=\mathrm{O}$ stretching vibrations and in the case of the treated sample these peaks were appeared at $1134-1361 \mathrm{~cm}^{-1}$. Additionally, the P-O stretching was observed at 1066 and $1068 \mathrm{~cm}^{-1}$ in the control and treated samples. The $\mathrm{P}-\mathrm{OH}$ out of plane bending vibrations were appeared at 530 and $542 \mathrm{~cm}^{-1}$ in the control and treated samples [29]. Overall, the result showed decrease in frequency of stretching peaks such as $3373 \rightarrow 3369$, $2893 \rightarrow 2879$, and $1390 \rightarrow 1361 \mathrm{~cm}^{-1}$ in the treated PBS as compared to the control. This might be due to decrease in force constant of these $\mathrm{O}-\mathrm{H}, \mathrm{C}-\mathrm{H}$ and $\mathrm{P}=\mathrm{O}$ groups in the treated sample. However, the frequency of $\mathrm{O}=\mathrm{P}-\mathrm{OH}$ deformation and $\mathrm{P}-\mathrm{OH}$ bending vibrations were increased $\left(530 \rightarrow 541 \mathrm{~cm}^{-1}\right.$ and $\left.1716 \rightarrow 1745 \mathrm{~cm}^{-1}\right)$ as compared to the control. It is assumed that biofield energy treatment might caused increase in force constant and strength of these bonds.

The FT-IR spectra of the control and treated HBS are presented in Fig. 9. The broad stretching vibration peak at $3242 \mathrm{~cm}^{-1}$ was due to $-\mathrm{OH}$ present in the calcium chloride of the control HBS. In treated sample, these peaks appeared at a higher frequency, $3392 \mathrm{~cm}^{-1}$ as compared to the control. The $\mathrm{C}-\mathrm{H}$ stretching vibrations peaks were assigned in the region of $2895-2937 \mathrm{~cm}^{-1}$ in the control HBS, while the treated sample showed these peaks at 2879-2939 $\mathrm{cm}^{-1}$. A characteristic stretching peak of calcium chloride phase was evidenced at $1444 \mathrm{~cm}^{-1}$ in the control sample, but it was shifted to a higher frequency in the treated HBS, $1448 \mathrm{~cm}^{-1}$. This might be due to increase in force constant of this particular group as compared to the control sample.

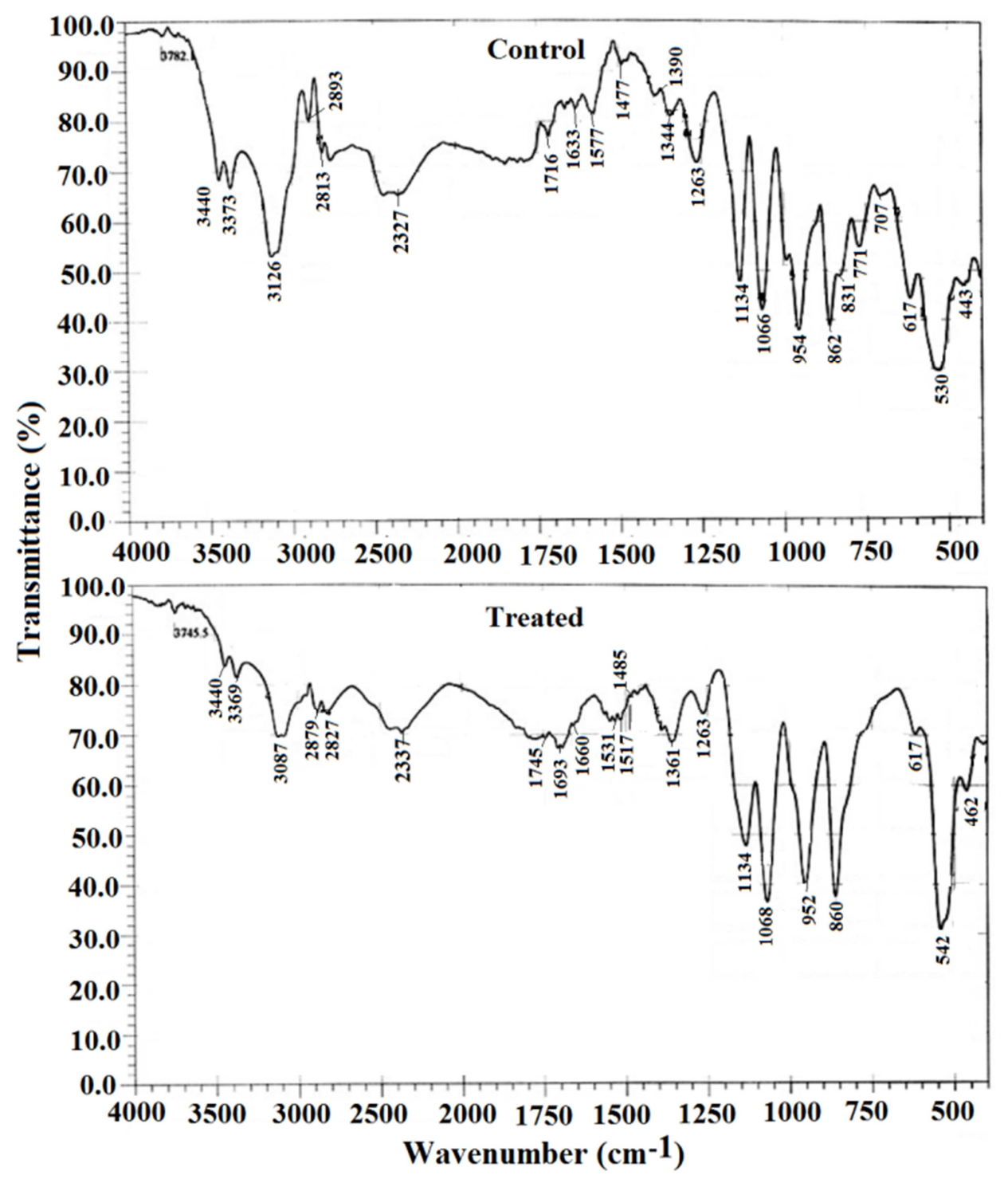

Figure 8. FT-IR spectra of control and treated phosphate buffer saline. 


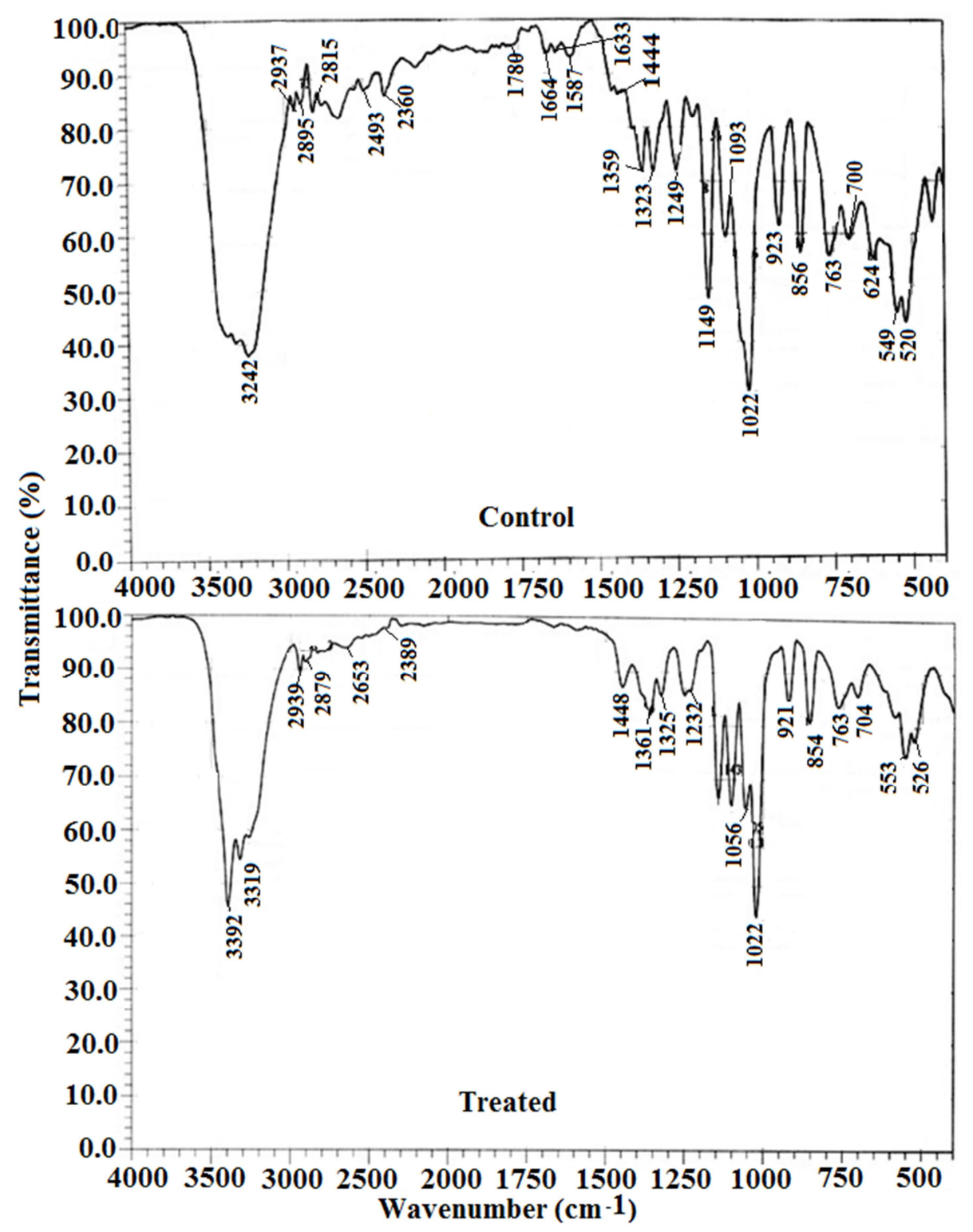

Figure 9. FT-IR spectra of control and treated hanks balanced salt.

\section{Conclusion}

In summary, the XRD results indicated increase in crystallite size by 5.20 and $3.20 \%$ in treated samples (PBS and HBS) as compared to the control. It is hypothesized that biofield treatment may provide thermal energy that caused increase in crystallite size with respect to the control samples (PBS and HBS). The DSC analysis showed disappearance of melting temperature in the treated PBS as compared to the control. This was perhaps due to rigid crystalline nature of the treated sample. However, the treated $\operatorname{HBS}\left(152.83^{\circ} \mathrm{C}\right)$ showed slight increase in the melting temperature with respect to the control $\left(150.60^{\circ} \mathrm{C}\right)$. Additionally, the latent heat of fusion was increased substantially by $108.83 \%$ in the treated HBS sample, when compared with the control. The TGA analysis showed increase in thermal stability of the treated samples (PBS and HBS) as compared to the control. The FT-IR spectroscopic evaluation showed the alteration in frequency of functional groups such as $\mathrm{O}-\mathrm{H}, \mathrm{C}-\mathrm{H}, \mathrm{P}=\mathrm{O}, \mathrm{O}=\mathrm{P}-\mathrm{OH}$, and $\mathrm{P}-\mathrm{OH}$ in the treated PBS. The FT-IR spectrum of the treated HBS showed some alteration in frequency of the calcium chloride phase $\left(1444 \rightarrow 1448 \mathrm{~cm}^{-1}\right)$ of the treated sample as compared to the control. Overall, the results showed that biofield treatment has changed the physical, thermal and spectral properties of the treated samples (PBS and HBS) with respect to the control. It is assumed that good thermal stability of the treated samples might make them a good candidate for biological and tissue culture applications.

\section{Abbreviations}

PBS: Phosphate buffer saline; HBS: Hank buffer salt; XRD: X-ray diffraction; DSC: Differential scanning calorimetry; TGA: Thermogravimetric analysis; FT-IR: Fourier transform infrared. 


\section{Acknowledgments}

The authors wish to thank all the laboratory staff of MGV Pharmacy College, Nashik for their kind assistance during handling the various instrument characterizations. The authors would also like to thank Trivedi Science, Trivedi Master Wellness and Trivedi Testimonials for their support during the work.

\section{References}

[1] Bolego C, Buccellati C, Prada A, Gaion RM, Folco G, et al. (2009) Critical role of COX-1 in prostacyclin production by human endothelial cells under modification of hydroperoxide tone. FASEB J 23: 605-612.

[2] Wang HL, Miyauchi M, Takata T (2002) Initial attachment of osteoblasts to various guided bone regeneration membranes: An in vitro study. J Periodontal Res 37: 340-344.

[3] Kalka C, Masuda H, Takahashi T, Kalka-Moll WM, Silver M, et al. (2000) Transplantation of ex vivo expanded endothelial progenitor cells for therapeutic neovascularization. PNAS 97: 3422-3427.

[4] Moldenhauer A, Nociari MM, Dias S, Lalezari P, Moore MA (2003) Optimized culture conditions for the generation of dendritic cells from peripheral blood monocytes. Vox Sang 84: 228-236.

[5] Pollreisz A, Assinger A, Hacker S, Hoetzenecker K, Schmid W (2008) Intravenous immunoglobulins induce CD32-mediated platelet aggregation in vitro. Br J Dermatol 159: 578-584.

[6] Jing R, Wang H, Jiang S, Zhang Z (2008) Up-regulation of the receptor for advanced glycation end product (RAGE) in esophageal cancer and down-regulation in lung cancer and their relationship to clinicopathological features. Lab Med 39: 661-667.

[7] Lichtenauer M, Nickl S, Hoetzenecker K, Mangold A, Moser B, et al. (2009) Phosphate buffered saline containing calcium and magnesium elicits increased secretion of interleukin-1 receptor antagonist. Lab Med 40: 290-293.

[8] Harfi I, Corazza F, DHondt S, Sariban E (2005) Differential calcium regulation of proinflammatory activities in human neutrophils exposed to the neuropeptide pituitary adenylate cyclase-activating protein. J Immunol 175: 4091-4102.

[9] http://ccc.chem.pitt.edu/wipf/Web/HPLC_RP_Buffers.pdf (Accessed on 19 October 2015).

[10] Nam JY, Kim HW, Lim KH, Shin HS, Logan BE (2010) Variation of power generation at different buffer types and conductivities in single chamber microbial fuel cells. Biosens Bioelectron 25: 1155-1159.

[11] http://himedialabs.com/TD/TL1010.pdf (Accessed on 23 October 2015).

[12] https://promega.wordpress.com/2011/02/25/what-makes-a-goo d-buffer (Accessed on 19 October 2015).
[13] Uchida S, Iha T, Yamaoka K, Nitta K, Sugano H (2012) Effect of biofield therapy in the human brain. J Altern Complement Med 18: 875-879.

[14] Suzuki K, Uchida S, Kimura T (2009) Safety and efficacy of biofield therapy in Japan. Soc Integr Med Jpn 2: 37-43.

[15] Barnes PM, Powell-Griner E, McFann K, Nahin RL (2004) Complementary and alternative medicine use among adults: United States, 2002. Semin Integr Med 2: 54-7.

[16] Dabhade VV, Tallapragada RR, Trivedi MK (2009) Effect of external energy on atomic, crystalline and powder characteristics of antimony and bismuth powders. Bull Mater Sci 32: 471-479.

[17] Trivedi MK, Tallapragada RM, Branton A, Trivedi A, Nayak G, et al. (2015) Biofield treatment: A potential strategy for modification of physical and thermal properties of indole. $\mathrm{J}$ Environ Anal Chem 2: 152.

[18] Trivedi MK, Patil S, Shettigar H, Bairwa K, Jana S (2015) Effect of biofield treatment on spectral properties of paracetamol and piroxicam. Chem Sci J 6: 98.

[19] Trivedi MK, Nayak G, Patil S, Tallapragada RM, Mishra R (2015) Influence of biofield treatment on physicochemical properties of hydroxyethyl cellulose and hydroxypropyl cellulose. J Mol Pharm Org Process Res 3: 126.

[20] Shinde V, Sances F, Patil S, Spence A (2012) Impact of biofield treatment on growth and yield of lettuce and tomato. Aust J Basic Appl Sci 6: 100-105.

[21] Trivedi MK, Patil S, Shettigar H, Bairwa K, Jana S (2015) Phenotypic and biotypic characterization of Klebsiella oxytoca: An impact of biofield treatment. J Microb Biochem Technol 7: 202-205.

[22] Inoue M, Hirasawa I (2013) The relationship between crystal morphology and XRD peak intensity on $\mathrm{CaSO}_{4} \cdot 2 \mathrm{H}_{2} \mathrm{O}$. J Cryst Growth 380: 169-175.

[23] Grzmil B, Kic B, Rabe M (2004) Inhibition of the anatase-rutile phase transformation with addition of $\mathrm{K}_{2} \mathrm{O}, \mathrm{P}_{2} \mathrm{O}_{5}$, and $\mathrm{Li}_{2} \mathrm{O}$. Chem Pap 58:410-414.

[24] Jacob R, Nair HG, Isac J (2014) Optical band gap analysis of nano-crystalline ceramic PbSrCaCuO. JAP 5: 3.

[25] Jacob R, Isac J (2014) Band gap energy profile of bsft (basr.9fe.1tio4). IJSRP 12: 1-6.

[26] Kumar S, Tsai CJ, Nussinov R (2000) Factors enhancing protein thermostability. Protein Eng 13: 179-191.

[27] Szabo L, Cik G, Lensy J (1996) Thermal stability increase of doped poly (hexadecylthiophene) by $\gamma$-radiation. Synt Met 78: 149-153.

[28] Colthup NB (1975) Introduction to infrared and Raman spectroscopy. (2ndedn) Academic press. Inc., New York.

[29] Portia SAU, Jayanthi K, Ramamoorthy K (2014) Growth and characterization of pure and disodium hydrogen phosphate mixed with potassium dihydrogen phosphate crystal by using slow evaporation technique. Am J Biol Pharm Res 1: 77-82. 